\title{
Improved lipase biosynthesis by a newly isolated Penicillium sp. grown on agricultural wastes
}

\section{Elisandra Rigo, ${ }^{1}$ Jorge L. Ninow, ${ }^{1}$ André E. Polloni, ${ }^{2}$ Daniela Remonatto, ${ }^{2}$ Francieli Arbter, ${ }^{2}$ Renata Vardanega, ${ }^{2}$ Débora de Oliveira, ${ }^{2}$ Helen Treichel, ${ }^{2 *}$ and Marco Di Luccio ${ }^{2}$}

'Departamento de Engenharia Química e de Alimentos, Universidade Federal de Santa Catarina, UFSC, SC, Brasil

2Programa de Pós-Graduação em Engenharia de Alimentos, Universidade Regional Integrada do Alto Uruguai e das Missões-Campus de Erechim, Av. Sete de Setembro, 1621, 99700-000, Erechim, RS, Brasil

${ }^{*}$ Corresponding author

Tel: +55 5435209000

Fax: +55 5435209090

E-mail: helen@uricer.edu.br

Submitted: 31 Dec 2008; Revised: 17 Feb 2009; Accepted: 18 May 2009

\section{KEYWORDS}

lipase, Penicillium sp., solid state fermentation, soybean bran, agro-industrial substrate

\section{Abstract}

The main objective of this work was the optimization of the lipase production by a newly isolated Penicillium sp. in supplemented soybean meal, considering a fixed $C / N$ ratio (6.11). The kinetic behavior of lipase production was also evaluated, quantifying activity at different $p H$. The production of the enzyme was maximum using a substrate particle size between 1 and $2 \mathrm{~mm}$ and inoculum concentration of $2 \times 10^{8}$ spores $\bullet g^{-1}$, at $20^{\circ} \mathrm{C}$. Lipase activities of about $200 \mathrm{U} \cdot \mathrm{g}^{-1}$ at pH 4.0 were obtained after 120 h of cultivation, but activities at $p H$ 7.0 as high as $317 \mathrm{U} \cdot \mathrm{g}^{-1}$ could be obtained after $96 \mathrm{~h}$. The activities measured at pH 9.0 were also promising, ranging from 177 to 191 $\mathrm{U} \cdot \mathrm{g}^{-1}$. The results obtained are relevant, since high lipase activities, in a wide range of $\mathrm{pH}$ (4.0 to 9.0) were obtained from a newly isolated microorganism in a low-cost fermentation medium. The variation in the $C / N$ ratio at the previously optimized conditions showed that the best results were obtained at $C / N$ of 6.11 .

\section{Introduction}

ipases (triacylglycerol acylhydrolases EC 3.1.1.3) are a class of hydrolases that catalyze the hydrolysis of triglycerides to glycerol and free fatty acids at an oil-water interface. In addition, lipases can catalyze the hydrolysis of other esters and also reactions of synthesis of esters, transesterification, and interesterification, and may show enantioselective properties. Their ability to perform very specific chemical transformations has made lipases increasingly popular in the food, detergent, cosmetic, organic synthesis, and pharmaceutical industries. ${ }^{1-4}$

Several different lipase-production techniques have been developed in the search for higher yields and more-specific and morestable lipases, to enable more industrial applications. ${ }^{5-6}$ Solid state fermentation (SSF) is characterized by the growth of the microorganism in the absence of free water. This kind of technique can be used for production of many bioproducts, to add value to agro-industrial residues, and to increase nutritional quality and antioxidant activities of agro-wastes for use as animal feed..$^{6,7}$ SSF has been presented as an interesting alternative to the production of microbial enzymes. The use of agro-industrial residues can be a feasible means of decreasing the final cost of the enzyme. ${ }^{6,8-10}$

Studies on lipase production by SSF with different substrates combined to different fungi have been reported. ${ }^{10-12}$ Penicillium restrictum $^{13-15}$ and $P$. simplicissimum ${ }^{16-17}$ have been cultivated in babassu cake. Growth of $P$. simplicissimum ${ }^{18-19}$ and Penicillium verrucosum ${ }^{20}$ was studied in soybean meal. Other residues and microorganisms combinations have also been reported, such as nut residues using Rhizopus oligosporous ${ }^{21}$, sugarcane bagasse with $R$. rhizopodiformis, R. pusillus ${ }^{22}$ and $R$. homothallicus ${ }^{8,23}$, wheat bran with Aspergillus niger $^{24-25}$ and Mucor hiemalis ${ }^{26}$, a mix of wheat flour and wheat bran with $R$. chinensis ${ }^{27}$, and sesame (gingelly) oil cake with $A$. niger. ${ }^{28}$

The effect of medium composition, temperature, $\mathrm{pH}$, moisture content, inoculum concentration, and substrate porosity is of essential importance for bioprocess development. In a general sense, the enhancement on productivity is related to medium optimization. ${ }^{8,9,29-32}$ 
The measurement of enzymes activity in different $\mathrm{pH}$ values offers a way of screening different lipases, or a pool of them, considering that a variation in the fermentation medium can result in the production of different isoenzymes. ${ }^{33-34}$

In this context, this work aimed to optimize lipase production by SSF using a newly isolated strain of Penicillium sp. and soybean meal as both support and substrate. Different medium supplementations were tested, and the kinetic behavior was followed at different $\mathrm{pH}$. The influence of $\mathrm{C} / \mathrm{N}$ ratio in the lipase yield was also investigated.

\section{Materials \& methods}

\section{MICROORGANISM \& INOCULUM}

The microorganism used in this work was previously isolated from samples of soybean meal and identified as Penicillium sp..$^{35}$ The isolation of microorganisms and cultivation was carried out in Petri dishes using potato dextrose agar (PDA; Merck KGaA Darmstadt, Germany) medium at $30^{\circ} \mathrm{C}$. The screening was carried out by fermentation in soybean meal, and this strain was identified as a good lipase producer. Spores were maintained at $-10^{\circ} \mathrm{C}$ in cryotubes containing a $20 \%$ solution of glycerol in $9 \mathrm{~g} \cdot \mathrm{L}^{-1}$ aqueous $\mathrm{NaCl}$.

Erlenmeyer flasks (500 mL) with $100 \mathrm{~mL}$ of sterile PDA medium were inoculated with $0.5 \mathrm{~mL}$ of a spore suspension obtained from stock culture. Flasks were incubated for 7 days at $30^{\circ} \mathrm{C}$. Spores were collected by adding $20 \mathrm{~mL}$ of a solution of Tween $801 \mathrm{~mL} \cdot \mathrm{L}^{-1}$ in water and sterile glass beads to the flask. The resulting suspension was then used as inoculum, after adjusting the amount of spores to achieve the desired spore concentration, defined in the experimental design.

\section{SOLID STATE FERMENTATION}

The substrate and support used in all experiments was soybean meal from a same batch, obtained from a local soybean oil indus- try (Olfar SA; Erechim, Brazil). The meal is the residue of soybean oil extraction after cold press and extraction with $n$-hexane. The substrate was sieved, and the major fractions collected and stored at $-18^{\circ} \mathrm{C}$ until use. The three major fractions based on the particle diameter were 1-2 mm (Tyler 9-16; WS Tyler, division of Haver \& Boecker, Oelde, Germany), 0.5-1 mm (Tyler 16-32), and 0.25-0.50 mm (Tyler 32-60).

Fermentations were carried out with $10 \mathrm{~g}$ of dry soybean meal in tray reactors covered with hydrophobic fabric (Polysentric ${ }^{\circledR}$; Broomfield, Colorado, USA). The effect of composition of the cultivation medium, supplements, moisture content, particle size, inoculum concentration and temperature of fermentation on lipase production was evaluated by a strategy of sequential experimental designs.

After sterilization $\left(121^{\circ} \mathrm{C}\right.$ for $\left.15 \mathrm{~min}\right)$, each reactor was inoculated with the respective suspension of spores and incubated in a climatic chamber (TE 401, Tecnal; Piracicaba, Brazil) with humid air injection at a temperature defined by the factorial design.

Enzyme extraction was carried out using phosphate buffer (100 $\mathrm{mmol} \bullet \mathrm{L}^{-1}, \mathrm{pH}$ 7.0) at a solid-liquid ratio of 1:4 in an orbital shaker (MA 410; Marconi; Piracicaba, Brazil) at $150 \mathrm{rev} \bullet \mathrm{min}^{-1}, 35^{\circ} \mathrm{C}$ for 30 min. After filtration of solids, the supernatant was used for analytical assays. ${ }^{18-20}$

\section{MAXIMIZATION OF LIPASES PRODUCTION BY PENICILLIUM sp.}

Variables and studied range for the sequential experimental designs are presented in Table 1. The first was a PlackettBurman (PB12) type design, used for screening the statistically significant process variables that influence lipase production.

After statistical analysis of the first experimental design (PB12), a two-factor central composite rotational design (CCRD 2²) was carried

\section{Table 1. Ranges of the factors investigated in the three experimental designs}

\section{First Experimental Design (Plackett-Burman)}

\begin{tabular}{|c|c|c|c|c|c|}
\hline \multirow[b]{2}{*}{ Level } & \\
\hline & -1.41 & -1 & 0 & +1 & +1.41 \\
\hline Temperature $\left({ }^{\circ} \mathrm{C}\right)$ & - & 20 & 27 & 34 & - \\
\hline Moisture $\left(\mathrm{g} \bullet \mathrm{kg}^{-1}\right)$ & - & 350 & 550 & 750 & - \\
\hline Particle size $(\mathrm{mm})$ & - & $0.25-0.5$ & $0.5-1$ & $1-2$ & - \\
\hline Spore concentration (spores $\bullet \mathrm{g}^{-1}$ ) & - & $1.00 \times 10^{7}$ & $1.05 \times 10^{8}$ & $2.00 \times 10^{8}$ & - \\
\hline \multirow[t]{2}{*}{ Supplement ${ }^{*}\left(g \bullet \mathrm{kg}^{-1}\right)$} & - & 10.0 & 55.0 & 100.0 & - \\
\hline & \multicolumn{5}{|c|}{ Second Experimental Design $\left(2^{2}\right)$} \\
\hline Moisture $\left(g \bullet \mathrm{kg}^{-1}\right)$ & - & 550 & 650 & 750 & - \\
\hline \multirow[t]{2}{*}{ Supplement* $\left(g \bullet \mathrm{kg}^{-1}\right)$} & - & 6.0 & 18.0 & 30.0 & - \\
\hline & \multicolumn{5}{|c|}{ Third Experimental Design (CCRD $2^{2}$ ) } \\
\hline Moisture $\left(g \bullet \mathrm{kg}^{-1}\right)$ & 610 & 650 & 750 & 850 & 890 \\
\hline Supplement ${ }^{*}\left(g \bullet \mathrm{kg}^{-1}\right)$ & 1.0 & 2.4 & 6.0 & 9.5 & 11.0 \\
\hline
\end{tabular}

*Selected supplement concentration with soybean oil and urea ( $C / N$ of 6.11$)$ 
out at constant temperature, particle size, and spore concentration. In this design, the effect of moisture content and supplement concentration on lipase production was investigated.

Analysis of this second experimental design showed a need to shift the studied levels for the optimization of enzyme production. A third experimental design (CCRD $2^{2}$ ) was then carried out.

All analyses were performed in duplicate and triplicate at the central point of the experimental design. Statistical analysis was carried out using Statistica 6.1 software (Statsoft Inc., Tulsa, Oklahoma, USA).

\section{EFFECT OF C/N RATIO ON LIPASE PRODUCTION}

The effect of different carbon-to-nitrogen ratios (C/N of 2.00, 6.11, and 10.22) on lipase production was evaluated. Urea and soybean oil were added to achieve the desired $\mathrm{C} / \mathrm{N}$ ratios as presented in Table 2.

Table 2. Soybean oil and urea concentrations used to achieve the desired $\mathrm{C} / \mathrm{N}$ ratio

\begin{tabular}{ccc} 
C/N ratio & Soybean oil $\left(\mathrm{g} \bullet \mathrm{kg}^{-1}\right)$ & Urea $\left(\mathrm{g} \cdot \mathrm{kg}^{-1}\right)$ \\
\hline 2.00 & 2.0 & 41.2 \\
\hline 6.11 & 2.0 & 0.6 \\
\hline 10.22 & 39.5 & 0.6 \\
\hline
\end{tabular}

\section{DETERMINATION OF HYDROLYTIC ACTIVITY}

Lipase hydrolysis was assayed using an emulsion of olive oil (10 wt $\%$ ) in arabic gum (5 wt\%) in different buffers to evaluate lipase production, in terms of enzyme activity, at different $\mathrm{pH}$. Buffers used were sodium acetate $0.1 \mathrm{~mol} \bullet \mathrm{L}^{-1} \mathrm{pH} 4.0$, sodium phosphate 0.1 $\mathrm{mol} \bullet \mathrm{L}^{-1}, \mathrm{pH} 7.0$, and tris- $\mathrm{HCl} 0.1 \mathrm{~mol} \bullet \mathrm{L}^{-1}, \mathrm{pH}$ 9.0. After incubation for $15 \mathrm{~min}$ at $37^{\circ} \mathrm{C}$ and $160 \mathrm{rev} \bullet \mathrm{min}^{-1}$, the reaction was stopped by addition of a solution of acetone-ethanol (1:1). The fatty acids produced by the hydrolysis were titrated with $\mathrm{NaOH} 0.05 \mathrm{~mol} \bullet \mathrm{L}^{-1}$ in a pH-stat (Mettler-Toledo DL50; Columbus, Ohio, USA). Control assays (blanks) were carried out adding the acetone/ethanol solution right after enzyme addition. One unit of lipase activity was defined as the amount of enzyme preparation necessary to produce $1 \mu \mathrm{mol}$ of free acid per minute in the assay conditions. The results are expressed in terms of units per gram of dry substrate $\left(\mathrm{U} \bullet \mathrm{g}^{-1}\right) .^{18}$

\section{Results \& discussion}

\section{FIRST EXPERIMENTAL DESIGN}

The matrix of the Plackett-Burman experimental design (PB12) is presented in Table 3. The coded values of the variables temperature $\left({ }^{\circ} \mathrm{C}\right)$, moisture content $\left(\mathrm{g} \bullet \mathrm{kg}^{-1}\right)$, soybean meal particle size $(\mathrm{mm})$, spore concentration (spores. $\mathrm{g}^{-1}$ ), and supplementation (a mixture of urea and soybean oil, g• $\mathrm{kg}^{-1}$ ) concentration are also presented, as well as the response in terms of hydrolytic activity after $96 \mathrm{~h}$ of fermentation.

Table 3. Matrix of the first experimental design (PB) with coded values of the variables temperature $\left({ }^{\circ} \mathrm{C}\right.$ ), moisture content $\left(\mathrm{g} \cdot \mathrm{kg}^{-1}\right)$, particle size $(\mathrm{mm})$, spores (spores $\left.\bullet \mathrm{g}^{-1}\right)$, and supplement (urea plus soybean oil, $\mathrm{g} \cdot \mathrm{kg}^{-1}$ ) concentrations on lipase production after $96 \mathrm{~h}$ of fermentation

\section{Experimental Conditions}

Hydrolytic activity (U・g-1 dry soybean bran) $96 \mathrm{~h}$ of fermentation

\begin{tabular}{|c|c|c|c|c|c|c|c|c|}
\hline Run & $\mathrm{T}$ & MC & Particle Size & Spores & Supplement & $\mathrm{pH} 4.0$ & pH 7.0 & $\mathrm{pH} 9.0$ \\
\hline 1 & +1 & -1 & +1 & -1 & -1 & 16.20 & 0.65 & 2.70 \\
\hline 2 & +1 & +1 & -1 & +1 & -1 & 16.84 & 6.22 & 5.80 \\
\hline 3 & -1 & +1 & +1 & -1 & +1 & 43.49 & 97.26 & 70.01 \\
\hline 4 & +1 & -1 & +1 & +1 & -1 & 6.79 & 4.31 & 2.67 \\
\hline 5 & +1 & +1 & -1 & +1 & +1 & 13.39 & 37.62 & 10.54 \\
\hline 6 & +1 & +1 & +1 & -1 & +1 & 11.96 & 6.73 & 2.25 \\
\hline 7 & -1 & +1 & +1 & +1 & -1 & 204.27 & 266.18 & 177.68 \\
\hline 8 & -1 & -1 & +1 & +1 & +1 & 8.02 & 7.35 & 3.11 \\
\hline 9 & -1 & -1 & -1 & +1 & +1 & 16.02 & 22.14 & 4.53 \\
\hline 10 & +1 & -1 & -1 & -1 & +1 & 29.33 & 14.54 & 3.54 \\
\hline 11 & -1 & +1 & -1 & -1 & -1 & 147.12 & 175.85 & 200.96 \\
\hline 12 & -1 & -1 & -1 & -1 & -1 & 50.16 & 61.03 & 30.66 \\
\hline 13 & 0 & 0 & 0 & 0 & 0 & 129.85 & 123.85 & 97.13 \\
\hline 14 & 0 & 0 & 0 & 0 & 0 & 106.42 & 124.08 & 88.69 \\
\hline 15 & 0 & 0 & 0 & 0 & 0 & 106.28 & 121.54 & 102.34 \\
\hline
\end{tabular}


Run $7\left(20^{\circ} \mathrm{C}\right.$, moisture content $750 \mathrm{~g} \bullet \mathrm{kg}^{-1}$, particle size $1-2 \mathrm{~mm}$, $2 \times 10^{8}$ spores $\bullet \mathrm{mL}^{-1}$, and $10 \mathrm{~g} \bullet$ supplement $\left.\mathrm{kg}^{-1}\right)$ and Run $11\left(20^{\circ} \mathrm{C}\right.$, moisture content of $750 \mathrm{~g} \bullet \mathrm{kg}^{-1}$, particle size $0.25-0.50 \mathrm{~mm}, 1 \times 10^{7}$ spores $\bullet \mathrm{mL}^{-1}$, and supplement $10 \mathrm{~g} \bullet \mathrm{kg}^{-1}$ ) demonstrated higher lipase activities, at all tested $\mathrm{pH}$. It is worth noting that the lipase activities are high compared to others reported, which vary from 30 $\mathrm{U} \cdot \mathrm{g}^{-1}$ ( $P$. simplicissimun cultivated on soybean bran) to $40 \mathrm{U} \cdot \mathrm{g}^{-1}$ ( $P$. verrucosum cultivated on soybean bran) ${ }^{18,20}$, further demonstrating the potential of this microorganism for industrial applications.

Data in Table 3 was statistically treated and, from the five studied variables, three presented statistically significant effects $(\mathrm{p}<0.05)$ on lipase production. Temperature and supplement concentration showed a negative effect, and moisture content of the solid matrix a positive one, in lipase production. The observation of considerable activities (as per activity measurement) from the same experimental condition but different $\mathrm{pH}$ suggests that a pool of lipases was produced.

\section{SECOND EXPERIMENTAL DESIGN}

A second experimental design was carried out, based on the results obtained in the Plackett-Burman design, varying the ranges of moisture content and supplement concentration. The matrix of the second experimental design is presented in Table 4, where the respective responses in terms of hydrolytic activity after $96 \mathrm{~h}$ of fermentation could be found. Temperature, particle size, and spore concentration were kept constant at $20^{\circ} \mathrm{C}$, 1-2 $\mathrm{mm}$, and $2 \times 10^{8}$ spores $\bullet \mathrm{g}^{-1}$, respectively. The highest lipase activities $\left(200-300 \mathrm{U} \bullet \mathrm{g}^{-1}\right)$ were achieved in the experimental condition of Run 2, corresponding to a moisture content of $750 \mathrm{~g} \bullet \mathrm{kg}^{-1}$ and $6 \mathrm{~g} \bullet \mathrm{kg}^{-1}$ of supplement mix, which in turn correspond to the superior limits of these variables in the experimental design.

The statistical analysis of the experimental data resulted in an empirical coded model for lipase activities at $\mathrm{pH} 4.0$ and 7.0, which are presented in Equations 1 and 2, respectively. The models were validated by analysis of variance, which yielded correlation coefficients of 0.98 (at $\mathrm{pH} 4.0$ ) and 0.96 (at $\mathrm{pH}$ 7.0) and a good performance in F-test for regression (calculated values approximately 6.3 and 2.8 higher than those tabulated for pH 4.0 and 7.0, respectively). In Equations 1 and 2, LP4 and LP7 correspond to lipase production at $\mathrm{pH} 4$ and 7, respectively, $\mathrm{MC}$ is moisture content, and URSO ("urea soy"), the supplement concentration.

$L P 4=123.85+41.48 \bullet M C-38.51 \bullet U R S O-28.01 \bullet M C \bullet U R S O$

$L P 7=157.06+40.93 \bullet M C-37.80 \bullet U R S O-46.93 \bullet M C \bullet U R S O$

The hydrolytic activities measured at pH 9.0 after 96 h of fermentation at the experimental conditions presented in Table 4 indicated that the moisture content and the URSO concentration did not have a significant $(\mathrm{p}<0.05)$ effect on lipase production.
Table 4. Matrix of the second (CCRD $2^{2}$ ) experimental design with real and coded values of the variables moisture content $\left(\mathrm{MC} ; \mathrm{g} \cdot \mathrm{kg}^{-1}\right)$ and supplement concentration (urea plus soybean oil, $\mathbf{g} \cdot \mathrm{kg}^{-1}$ ) on lipase production after $96 \mathrm{~h}$ of fermentation

\begin{tabular}{|c|c|c|c|c|c|}
\hline \multirow[b]{3}{*}{ Run } & \multicolumn{2}{|c|}{ Experimental condition } & \multirow{2}{*}{\multicolumn{3}{|c|}{$\begin{array}{l}\text { Hydrolytic activity }\left(\mathrm{U} \cdot \mathrm{g}^{-1} \text { dry soybean bran) }\right. \\
96 \mathrm{~h} \text { of fermentation }\end{array}$}} \\
\hline & \multirow{2}{*}{$\begin{array}{c}\mathrm{MC} \\
\left(g \circ \mathrm{kg}^{-1}\right)\end{array}$} & \multirow{2}{*}{$\begin{array}{l}\text { Supplement } \\
\left(g \cdot \mathrm{kg}^{-1}\right)\end{array}$} & & & \\
\hline & & & $\mathrm{pH} 4.0$ & $\mathrm{pH} 7.0$ & pH 9.0 \\
\hline 1 & $-1(550)$ & $-1(6)$ & 93.27 & 107.23 & 74.25 \\
\hline 2 & +1 (750) & $-1(6)$ & 232.25 & 282.95 & 325.96 \\
\hline 3 & $-1(550)$ & $+1(30)$ & 72.26 & 125.48 & 65.84 \\
\hline 4 & +1 (750) & $+1(30)$ & 99.22 & 113.48 & 44.60 \\
\hline 5 & $0(650)$ & 0 (18) & 111.42 & 151.87 & 48.52 \\
\hline 6 & $0(650)$ & 0 (18) & 123.76 & 178.81 & 33.76 \\
\hline 7 & $0(650)$ & $0(18)$ & 134.77 & 139.64 & 34.22 \\
\hline
\end{tabular}

Table 5. Matrix of the third (CCRD $2^{2}$ ) experimental design with real and coded values of the variables moisture content $\left(\mathrm{MC} ; \mathrm{g}^{\circ} \mathrm{kg}^{-1}\right)$ and supplement concentration (urea plus soybean oil, $\mathrm{g} \cdot \mathrm{kg}^{-1}$ ) on lipase production after $96 \mathrm{~h}$ of fermentation

\begin{tabular}{|c|c|c|c|c|c|}
\hline \multirow[b]{2}{*}{ Run } & \multirow{2}{*}{$\begin{array}{c}M C \\
\left(g \circ \mathrm{kg}^{-1}\right)\end{array}$} & \multirow{2}{*}{$\begin{array}{l}\text { Supplement } \\
\left(\mathrm{g} \cdot \mathrm{kg}^{-1}\right)\end{array}$} & \multicolumn{3}{|c|}{$\begin{array}{l}\text { Hydrolytic activity }\left(\mathrm{U} \cdot \mathrm{g}^{-1} \text { dry soybean bran) }\right. \\
\qquad 6 \mathrm{~h} \text { of fermentation }\end{array}$} \\
\hline & & & pH 4.0 & pH 7.0 & pH 9.0 \\
\hline 1 & $-1(650)$ & $-1(2.4)$ & 129.30 & 144.92 & 172.48 \\
\hline 2 & +1 (850) & $-1(2.4)$ & 168.05 & 300.79 & 209.78 \\
\hline 3 & $-1(650)$ & +1 (9.5) & 106.38 & 175.83 & 176.49 \\
\hline 4 & +1 (850) & $+1(9.5)$ & 209.49 & 222.64 & 240.70 \\
\hline 5 & $0(750)$ & $0(6.0)$ & 173.68 & 330.02 & 317.68 \\
\hline 6 & $0(750)$ & $0(6.0)$ & 158.52 & 304.68 & 340.08 \\
\hline 7 & $0(750)$ & $0(6.0)$ & 161.55 & 317.34 & 324.36 \\
\hline 8 & $0(750)$ & $-1.41(1.0)$ & 167.74 & 197.02 & 310.90 \\
\hline 9 & $0(750)$ & $+1.41(11.0)$ & 136.48 & 200.17 & 276.53 \\
\hline 10 & $-1.41(610)$ & $0(6.0)$ & 95.90 & 112.58 & 173.16 \\
\hline 11 & +1.41 (890) & $0(6.0)$ & 139.42 & 195.67 & 143.68 \\
\hline
\end{tabular}




\section{THIRD EXPERIMENTAL DESIGN}

The results of the second experimental design suggested that for optimizing the lipase production, a third plan should be performed. The matrix of this experimental design with the respective responses in terms of hydrolytic activity is presented in Table 5. The kinetic behavior of the enzymatic activity measured at pH 4.0 (A), 7.0 (B) and 9.0
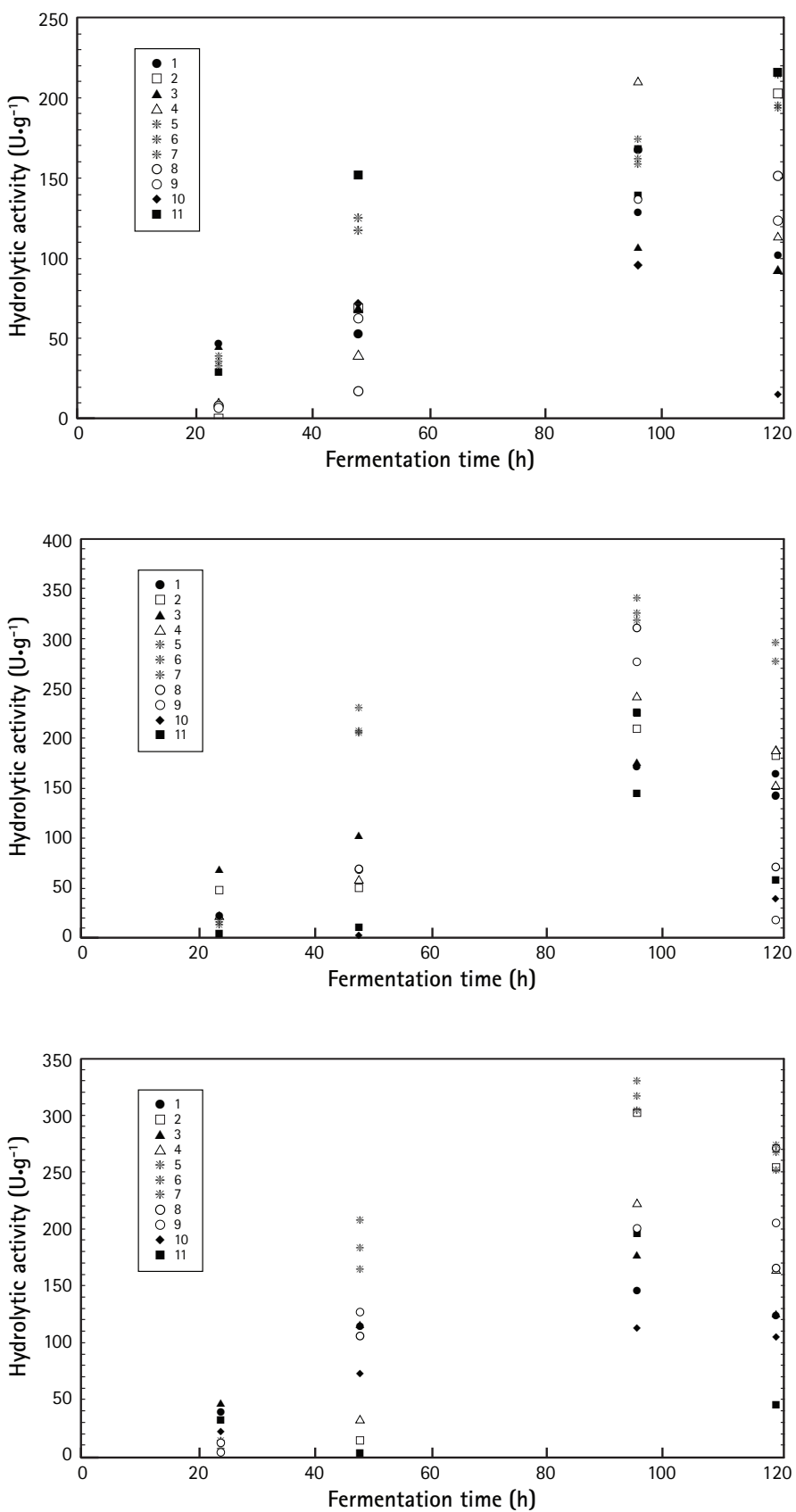

Figure 1. Kinetic behavior of lipase production in SSF measured at: $\mathrm{pH} 4.0$ (top), pH 7.0 (middle), and pH 9.0 (bottom), at experimental conditions presented in Table 5
(C), related to each experimental condition of Table 5, is presented in Figure 1.

The statistical analysis was carried out with the data from $96 \mathrm{~h}$ of fermentation, since more-pronounced differences were observed at this fermentation duration. When monitoring activity at $\mathrm{pH} 4.0$, neither moisture content nor supplement concentration showed significant $(\mathrm{p}<0.05)$ effects on lipase production. Equation 3 gives the coded empirical model for lipase production measured at $\mathrm{pH}$ 7.0, which was validated by analysis of variance, yielding a correlation coefficient of 0.79 , and calculated F-test regression of 1.15. The empirical model generated a response surface shown in Figure 2.

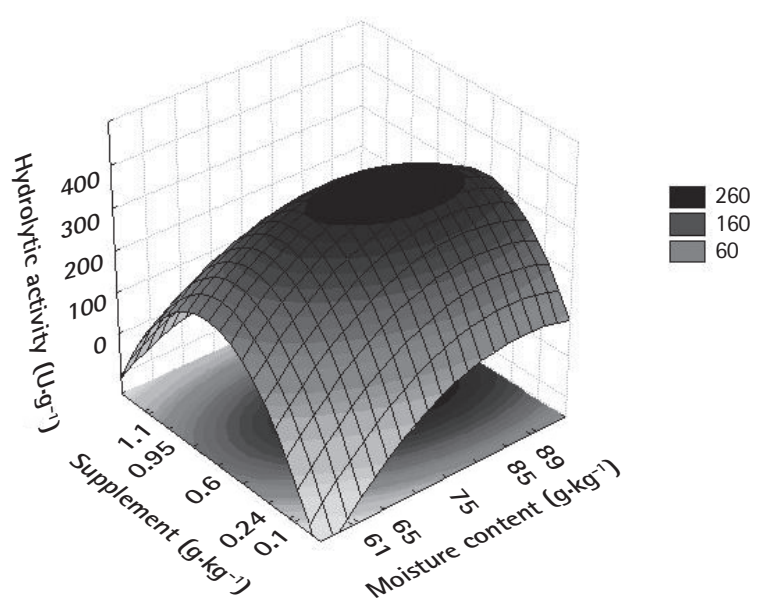

Figure 2. Response surface for lipase production measured at $\mathrm{pH} 7.0$ after 96 hours of fermentation, as a function of moisture content and supplement concentration

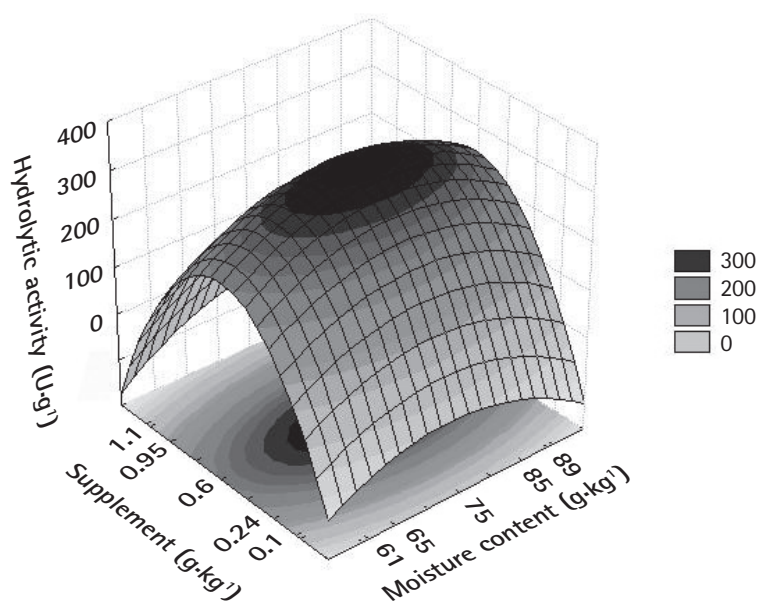

Figure 3. Response surface for lipase production measured at $\mathrm{pH} 9.0$ after 96 hours of fermentation, as a function of moisture content and supplement concentration 


$$
\begin{aligned}
L P 7= & 304.54+25.97 \bullet M C-44.37 \bullet M C^{2}+8.76 \bullet \\
& U R S O-66.74 \bullet U R S O^{2}-27.26 \bullet M C \bullet U R S O
\end{aligned}
$$

Equation 4 presents the coded empirical model for lipase production measured at $\mathrm{pH}$ 9.0, which was validated by analysis of variance with a correlation coefficient of 0.90 and F-test for regression of 2.70. The empirical coded model generated a response surface presented in Figure 3.

$$
\begin{aligned}
L P 9= & 327.47+6.65 \bullet M C-23.41 \bullet M C^{2}-0.83 \bullet \\
& U R S O-91.46 \bullet U R S O^{2}-6.72 \bullet M C \bullet U R S O
\end{aligned}
$$

The results presented herein suggest that the newly isolated microorganism is able to produce a pool of lipases with potential for industrial applications, presenting high activities of 201.11 and 177.64 $\left(\mathrm{U} \bullet \mathrm{g}^{-1}\right.$ dry soybean bran) at $96 \mathrm{~h}$ at $\mathrm{pH} 4.0$ and 9.0, respectively. These results accord with those of other reported studies that indicate that the use of a supplementary carbon source in SSF can favor the synthesis of different enzymes. ${ }^{15}$ The low amount of urea added to the fermentation medium should not be considered economically inconvenient, as it is a relatively low-cost compound.

The use of inducers in the production of lipases has been reported elsewhere. The most-studied inducers include olive $e^{27,36}$ and soybean oil. ${ }^{37}$ Lipase productivity, however, is affected by the medium supplementation added. The addition of vegetable oils to the fermentation medium can also cause inhibition, decreasing lipase production, possibly due to the action of proteases. ${ }^{38}$

The use of urea has also been reported by Rodriguez et $\mathrm{al}^{8}$ and Diaz et $\mathrm{al} ;{ }^{23}$ those studies of supplementation of sugarcane bagasse with urea and soybean oil demonstrated that supplementation can increase lipase production by $R$. homothallicus up to sixtyfold when compared to basal medium. Alkan et $\mathrm{al}^{39}$ also showed that the addition of urea and olive oil $\left(10 \mathrm{~g} \bullet \mathrm{kg}^{-1}\right)$ improved lipase production by SSF using sugarcane bagasse and Bacillus coagulans.

\section{EFFECT OF C/N RATIO ON LIPASE PRODUCTION AT OPTI- MIZED EXPERIMENTAL CONDITIONS}

The effect of different carbon and nitrogen $(\mathrm{C} / \mathrm{N})$ ratios on lipase production was evaluated at the experimental conditions of the central point (Table 5). The temperature, particle size, spore concentration, moisture content, and supplement concentration were kept constant at $20^{\circ} \mathrm{C}, 1-2 \mathrm{~mm}, 2 \times 10^{8}$ spores $\bullet \mathrm{g}^{-1}, 750 \mathrm{~g} \bullet \mathrm{kg}^{-1}$, and $6 \mathrm{~g} \bullet \mathrm{kg}^{-1}$, respectively. The $\mathrm{C} / \mathrm{N}$ ratio at these conditions was 6.11 , which was the ratio of soybean meal and all tested media in these experiments. The results from this step are presented in Table 6. Significant differences $(\mathrm{p}<0.05)$ among the lipase activities were obtained at different $\mathrm{C} / \mathrm{N}$ ratios for each $\mathrm{pH}$ tested, but $\mathrm{C} / \mathrm{N}$ ratios other than 6.11 did not lead to enhanced lipase production, although good activities $(>100$ $\mathrm{U} \cdot \mathrm{g}^{-1}$ ) could be obtained at $\mathrm{C} / \mathrm{N}$ ratio of 10.2.

Mahadik et $\mathrm{al}^{25}$ observed that lipase production was highly influenced by carbon content on fermentation media. It seems that this behavior is directly related to the microorganism's regulation
Table 6. Effect of different carbon and nitrogen

\begin{tabular}{|c|c|c|c|}
\hline \multirow[b]{2}{*}{$\mathrm{C} / \mathrm{N}$ ratio } & \multicolumn{3}{|c|}{ Hydrolytic activity (U.g $\mathrm{g}^{-1}$ of soybean bran) } \\
\hline & $\mathrm{pH} 4.0$ & $\mathrm{pH} 7.0$ & pH 9.0 \\
\hline 2.00 & $14.86^{\mathrm{a}} \pm 2.09$ & $18.62^{\mathrm{a}} \pm 6.24$ & $14.97^{\mathrm{a}} \pm 7.88$ \\
\hline 6.11 & $197.18^{b} \pm 3.45$ & $301.26^{b} \pm 5.07$ & $309.05^{b} \pm 2.34$ \\
\hline 10.2 & $101.97^{c} \pm 0.78$ & $165.45^{\mathrm{C}} \pm 2.68$ & $117.25^{c} \pm 2.88$ \\
\hline \multicolumn{4}{|c|}{$\begin{array}{l}\text { *Means } \pm \text { standard error followed by different superscripts in the same column, } \\
\text { in same } \mathrm{pH} \text { in } 96 \mathrm{~h} \text { of fermentation are significantly different }(p<0.05) \text { by Tukey's } \\
\text { test. }\end{array}$} \\
\hline
\end{tabular}
concentrations on lipase production measured at pH 4.0, 7.0, and 9.0, at 96 hours of fermentation, using soybean meal as substrate and Penicillium sp.

mechanism; accordingly, some studies have related that medium supplementation with lipids is not efficient. ${ }^{28}$ Supplementation with $10 \mathrm{~g} \bullet \mathrm{kg}^{-1}$ of tributyrin led to the maximum alkaline lipase production using Pseudomonas sp. The use of other complementary carbon sources does not necessarily increase lipase production, as shown by Kiran et al. ${ }^{40}$ The presence of other carbon sources, like sugars, may strongly inhibit lipase production, via catabolic repression. In some cases, carbon limitation may increase lipase production..$^{40}$ In the present work, the increase in the carbon source to detriment of nitrogen caused first an increase, then a decrease, in lipase production, which is in agreement with the observations of Kiran et $\mathrm{al}^{40}$ and Mahadik et al. ${ }^{25}$ Azeredo et $\mathrm{al}^{13}$ showed that the ideal $\mathrm{C} / \mathrm{N}$ ratio for lipase production by $P$. restrictum using babassu cake as substrate was 13.13 ; that data indicated peak production after $24 \mathrm{~h}$ of fermentation $\left(17.4 \mathrm{U} \cdot \mathrm{g}^{-1}\right)$ when olive oil was used. Gombert et $\mathrm{al}^{15}$ showed that the increase in $\mathrm{C} / \mathrm{N}$ ratio from 11.7 to 14.0 could lead to higher lipase production by $P$. restrictum in babassu cake. Our studies indicate that the excess of carbon source seems to be inhibitory to lipase production, and higher yields are obtained at lower $\mathrm{C} / \mathrm{N}$ ratios (6.11).

The presence of a nitrogen source reportedly is not an absolute requirement for the production of lipase. Kiran et $\mathrm{al}^{40}$ showed that supplementation of liquid medium with peptone, casein, and meat extract inhibits lipase production; however, higher yields are obtainable when the medium is supplemented with urea and corn steep liquor. ${ }^{41,42}$

\section{Conclusions}

The kinetic evaluation of the fermentative process using Penicillium sp. showed that medium supplementation improved the production of the enzyme. Optimal lipase production was found in soybean bran supplemented with $6 \mathrm{~g} \bullet \mathrm{kg}^{-1}$ of urea and soybean oil (C/N 6.11), at different $\mathrm{pH}$, moisture content $750 \mathrm{~g} \bullet \mathrm{kg}^{-1}$, particle size between 1 and 2 $\mathrm{mm}$, a temperature of $20^{\circ} \mathrm{C}$, and with a spore concentration of $2 \times 10^{8}$ spores $\bullet \mathrm{g}^{-1}$. Lipase production as high as $317 \mathrm{U} \bullet \mathrm{g}^{-1}$ of dry soybean bran could be obtained at $96 \mathrm{~h}$ and $\mathrm{pH}$ 4.0. The effect of the $\mathrm{C} / \mathrm{N}$ ratio on lipase production indicated that the optimal ratio was that of the crude soybean meal (6.11). These results demonstrate that a pool of lipases with high activities at $\mathrm{pH}$ ranging from 4.0 to 9.0 are obtainable. 


\section{OPTIMIZATION OF LIPASE HYDROLYTIC ACTIVITY}

\section{Acknowledgments}

The authors thank Coordenação de Aperfeiçoamento de Pessoal de Nivel Superior (CAPES)/Programa de Cooperação Acadêmica (PROCAD), Conselho Nacional de Desenvolvimento Científico e Tecnológico (CNPq), and Instaladora Técnica Industrial (Intecnial) for financial support of this work.

\section{REFERENCES}

1. Saxena RK, Sheoran A, Bhoopander G, and Davidson WS. Purification strategies for microbial lipases. J Microbiol Method 52, 1-18 (2003).

2. Shimada $Y$, Watanabe $Y$, Sugihara A, and Tominaga $Y$. Enzymatic alcoholysis for biodiesel fuel production and application of the reaction to oil processing. J Molec Catalysis 17, 133-142 (2002).

3. Pandey A, Benjamin $S$, Soccol CR, Nigam P, Krieger N, and Soccol VT. The realm of microbial lipases in biotechnology. Biotechnol Appl Biochem 29, 119-131 (1999).

4. Jaeger KE, and Reetz MT. Microbial lipases form versatile tools for biotechnology. Tibtech 16, 396-403 (1998).

5. Liu CH, Chen WM, and Chang JS. Methods for rapid screening and isolation of bacteria producing acidic lipase: feasibility studies and novel activity assay protocols. World J Microbiol Biotechnol 23, 633-640 (2007).

6. Soccol CR, and Vandenberghe LPS. Overview of applied solid-state fermentation in Brazil. Biochem Eng J 13, 205-218 (2003).

7. Lateef A, Oloke JK, Gueguim Kana EB, Oyeniyi SO, Onifade OR, Oyeleye AO, Oladosu OC, and Oyelami AO. Improving the quality of agro-wastes by solid-state fermentation: Enhanced antioxidant activities and nutritional qualities. World J Microbiol Biotechnol 24, 2369-2374 (2008).

8. Rodriguez JA, Mateos JC, Nungaray J, González V, Bhagnagar T, Roussos S, Cordova J, and Baratti J. Improving lipase production by nutrient source modification using Rhizopus homothallicus cultured in solid state fermentation. Process Biochem 41, 2264-2269 (2006).

9. Pandey A. Solid state fermentation. Biochem Eng J 13, 81-84 (2003).

10. Castilho LR, Polato CMS, and Buarque EA. Ecomomic analysis of lipase production by Penicillium restrictum in solid-state submerged fermentations. Biochem Eng J 4, 239-247 (2000).

11. Nagel FJ, Oostra J, Tramper J, and Rinzema A. Improved model system for solidsubstrate fermentation: effects of $\mathrm{pH}$, nutrients and buffer on fungal growth rate. Process Biochem 35, 69-75 (1999).

12. Holker $U$, Hofer $M$, and Lenz J. Biotechnological advantages of laboratory-scale solid-state fermentation with fungi. Appl Microbiol Biotechnol 64, 175-186 (2004).

13. Azeredo LAl, Gomes PM, Sant'Anna Jr GL, Castilho LR, and Freire DMG. Production and regulation of lipase activity from Penicillium restrictum in submerged and solid-state fermentations. Curr Microbiol 54, 361-365 (2007).

14. Palma MB, Pinto AL, Gombert AK, Seitz KH, Kivatinitz SC, Castilho LR, and Freire DMG. Lipase Production by Penicillium restrictum using solid waste of industrial babassu oil production as substrate. Appl Biochem Biotechnol 84-86, 1137-1145 (2000).

15. Gombert AK, Pinto AL, Castilho LR, Freire DMG. Lipase production by Penicillium restrictum in solid-state fermentation using babassu oil cake as substrate. Process Biochem 35, 85-90 (1999).
16. Gutarra MLE, Cavalcanti EDC, Castilho LR, and Freire DMG. Lipase production by solid-state fermentation. Appl Biochem Biotechnol 121-124, 105-116 (2005).

17. Cavalcanti EAC, Gutarra MLE, and Freire DMG. Lipase production by solid-state fermentation in fixed-bed bioreactors. Braz Arch Bio Technol 48, 79-84 (2005).

18. Vargas GDLP, Treichel H, Oliveira D, Beneti SC, Freire DMG, and Di Luccio M. Optimization of lipase production by Penicillium simplicissimum in soybean meal. J Chem Technol Biotechnol 83, 47-54 (2008).

19. Di Luccio M, Capra F, Ribeiro NP, Vargas GDLP, Freire DMG, and Oliveira D. Effect of temperature, moisture, and carbon supplementation on lipase production by solid-state fermentation of soy cake by Penicillium simplicissimum. Appl Biochem Biotechnol 113-116, 173 (2004).

20. Kempka AP, Lipke NL, Pinheiro TLF, Menoncin S, Treichel H, Freire DMG, and Di Luccio M. Response surface method to optimize the production and characterization of lipase from Penicillium verrucosum in solid state fermentation. Bioprocess Biosyst Eng 31, 119-125 (2008).

21. Ul-Haq I, Idrees S, and Rajoka MI. Production of lipases by Rhizopus oligosporous by solid-state fermentation. Process Biochem 37, 637-641 (2002).

22. Cordova J, Nemmaoui M, Ismaili-Alaoui M, Morin A, Roussos S, Raimboult M, and Benjilali B. Lipase production by solid state fermentation of olive cake and sugar cane bagasse. J Molecular Catalysis 5, 75-78 (1998).

23. Diaz JC, Rodriguez JA, and Roussos S. Lipase from the thermotolerant fungus Rhizopus homothallicus is more thermostable when produced using solid state fermentation than liquid fermentation procedures. Enzyme Microb Techno/ 39, 1042-1050 (2006)

24. Dutra JCV, Terzi SC, and Bevilaqua JV. Lipase production in solid-state fermentation monitoring biomass growth of Aspergillus niger using digital image processing. Appl Biochem Biotechnol 147, 63-75 (2008).

25. Mahadik ND, Puntambekar US, Bastawde KB, Khire JM, and Gokhale DV. Production of acidic lipase by Aspergillus niger in solid state fermentation. Process Biochem 38, 715-721 (2002).

26. Nagy V, Toke ER, Keong LC, Szazker G, Ibrahim D, and Omar I. Kinetic resolutions with novel, highly enantioselective fungal lipases produced by solid state fermentation. J Mol Catalysis 39, 141-148 (2006).

27. Sun SY, and Xu Y. Solid-state fermentation for whole-cell synthetic lipase production from Rhizopus chinensis and identification of the functional enzyme. Process Biochem 43, 219-224 (2008).

28. Kamini NR, Mala JGS, and Puvanakrishnan R. Lipase production from Aspergillus niger by solid-state fermentation using gingelly oil cake. Process Biochem 33, 505-511 (1998).

29. Holker U, and Lenz J. Solid-state fermentation-Are there any biotechnological advantages? Curr Opin Microbiol 8:301-306 (2005).

30. Chen HZ, Xu J, and Li ZH. Temperature control at different bed depths in a novel solid-state fermentation system with two dynamic changes of air. Biochem Eng J 23, 117-122 (2005).

31. Couto SR, and Sanromán MA. Application of solid-state fermentation to food industry-A review. J Food Eng 76, 291-302 (2005).

32. Raghavarao KSMS, Ranganathan TV, and Karanth NG. Some engineering aspects of solid-state fermentation. Biochem Eng J 13, 127-135 (2003).

33. Zarevúcka M, Kejik Z, Saman D, Wimmer D, and Demnevorá Z. Enantioselective properties of induced lipases from Geotrichum. Enzyme Microb Techno/ 37, 481486 (2005). 
ORIGINAL RESEARCH

34. Saxena RK, Davidson WS, Sheoran A, and Giri B. Purification and characterization of an alkaline thermostable lipase from Aspergillus carneus. Process Biochem 39, 239-247 (2003).

35. Griebeler N, Polloni AE, Remonatto $D$, Arbter $F$, Vardanega $R$, Cechet JL, Di Luccio M, de Oliveira D, Treichel H, Cansian RL, Rigo E, and Ninow JL. Isolation and screening of lipase-producing fungi with hydrolytic activity. Food Bioprocess Technol DOI: 10.1007/s11947-008-0176-5 (2009).

36. Gupta N, Sahai V, and Gupta R. Alkaline lipase from a noval strain Burkholderia multivarans: Statistical medium optimization and production in a bioreactor. Process Biochem 42, 518-526 (2007).

37. Silva WOB, Mitidieri S, Schrank A, and Vainstein MH. Production and extraction of an extracellular lipase from the entomopathogenic fungus Metarhizium anisophae. Process Biochem 40, 321-326 (2005).

38. Takac $S$, and Marul B. Effects of lipidic carbon sources on the extracellular lipolytic activity of a newly isolated strain of Bacillus subtilis. J Ind Microbiol Biotechnol 35, 1019-1025 (2008).

39. Alkan H, Baysal Z, Uyar F, Dogru M. Production of lipase by newly isolated Bacillus coagulans under solid-state fermentation using melon wastes. Appl Biochem Biotechnol 136, 183-192 (2007)

40. Kiran SG, Shanmughapriya S, Jayalakshmi J, Selvin J, Gandhimathi R, Sivaramakrishnan S, Arunkumar M, Thangavelu T, and Natarajaseenivasan K. Optimization of extracellular psychrophilic alkaline lipase produced by marine Pseudomonas sp. (MSI057). Bioprocess Biosyst Eng 31, 483-492 (2008).

41. Deive FJ, Costas $M_{1}$ and Longo MA. Production of thermostable extracellular lipase by Kluyveromyces marxianus. Biotechnol Lett 25, 1403-1406 (2003).

42. Burkert JFM, Maugeri F, and Rodrigues MI. Optimization of extracellular lipase production by Geotrichum sp. using factorial design. Bioresour Technol 91, 77-84 (2004). 